\title{
Pengembangan Zakat Untuk Perekonomian Masyarakat
}

\author{
Hasanuri \\ UIN Alauddin Makassar \\ E-mail :
}

\begin{abstract}
Abstrak,
Penulisan tesis ini bertujuan untuk mengetahui pengaruh pemberdayaan zakat terhadap pengembangan ekonomi umat di Kota Kendari, yang diawali dengan upaya mengetahui bagaimana peranan zakat bagi pengembangan ekonomi umat di Kota Kendari, langkah strategis yang harus ditempuh dalam pemberdayaan zakat, kemudian diakhiri pembahasannya dengan mengupas pengaruh pemberdayaan zakat terhadap pengembangan ekonomi umat di Kota Kendari.

Jenis penelitian ini adalah deskriptif kualitatif.

Hasil penelitian menunjukkan bahwa keberadaan lembaga pengelola zakat (BAZDA) dan kinerjanya belum menunjukkan adanya hasil sebagaimana yang diharapkan dalam upaya menumbuhkan ekonomi umat, meningkatkan kesejahteraan dan mengentaskan kemiskinan di Kota Kendari. Hal ini disebabkan oleh karena faktor lembaga pengelola zakat itu sendiri (BAZDA) yang belum optimal dalam menggali dan merealisasikan potensi zakat. Programprogram yang dilaksanakan selama ini masih pada tataran sosialisasi dan upaya menumbuhkan kesadaran umat Islam dalam membayar zakat, belum menyentuh pada pola pemberdayaan yang dapat meningkatkan kesejahteraan dan mengangkat taraf hidup kaum $d u$ 'afa. Namun demikian masyarakat tetap yakin dan optimis, bahwa jika potensi zakat di Kota Kendari mampu direalisasikan dan dikelola oleh lembaga pengelola yang amanah, profesional dan bertanggung jawab, niscaya akan dapat meningkatkan kesejahteraan umat, mengentaskan kemiskinan dan dapat mempengaruhi pertumbuhan ekonomi umat di Kota Kendari.
\end{abstract}

Kata Kunci: Zakat, Badan Amil, Perekonomian, Dhuafa.

\section{PENDAHULUAN}

Sesungguhnya, kalau dicermati sejarah umat Islam, maka peradaban Islam tidak dapat dilepaskan dari zakat. Bahkan, menurut Ahmad Juwaeni--salah seorang dinamisator zakat Indonesia. sebagaimana dikutip oleh Irfan Syauqi Beik dalam Peradaban Zakat Jilid Dua, dikatakan bahwa tidak mungkin peradaban Islam akan tegak tanpa optimalnya pengelolaan zakat. Lebih lanjut dikatakan bahwa adanya sekelompok orang yang memiliki dedikasi tinggi sebagai amil zakat merupakan prasyarat agar kegemilangan peradaban masa lalu dapat kembali diwujudkan di masa yang akan datang. (Beik, 2008)

Penulis menyadari bahwa untuk mewujudkan hal tersebut tidaklah mudah. Adanya anggapan bahwa zakat tidak memiliki pengaruh yang signifikan terhadap pertumbuhan ekonomi, karena persentasenya sangat kecil, yaitu hanya 2,5 persen. Bagaimana mungkin zakat akan mampu mempengaruhi, misalnya, pertumbuhan ekonomi suatu negara atau daerah dengan persentase sebesar itu?

Munculnya keragu-raguan tersebut adalah karena hingga saat ini belum ada satu negara muslim pun yang dapat dijadikan sebagai model yang tepat. Malaysia misalnya, memiliki keunggulan dalam hal penghimpunan zakat dibandingkan Indonesia. Namun demikian, dalam 
hal pendayagunaan zakat, justru Indonesia yang lebih unggul dibandingkan Malaysia. Indonesia memiliki kreativitas yang lebih tinggi dibandingkan negara-negara muslim lainnya dalam hal pemberdayaan dana ZIS. Akan tetapi, karena dana zakat yang ada di Indonesia jumlahnya masih sangat kecil, yaitu kurang dari 1 persen dari total GDP, maka 'seolah-olah' ada tidaknya zakat tidak mempengaruhi perekonomian secara makro.

Rasulullah saw., dalam sebuah hadis șahih yang diriwayatkan oleh Ibnu Abbas r.a. menyatakan:

$$
\begin{aligned}
& \text { حدثنا أبو عاصم الضحاك بن مَخْلَدٍ عن زكرياء ابن إسحاق عن يحي بن عبد الله بن صَيِْْيّ عن أبى سعيد عن ابن عبّاس }
\end{aligned}
$$

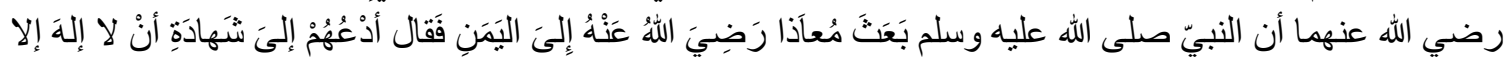

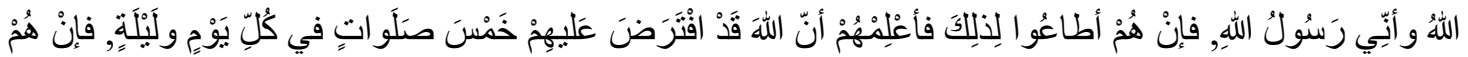

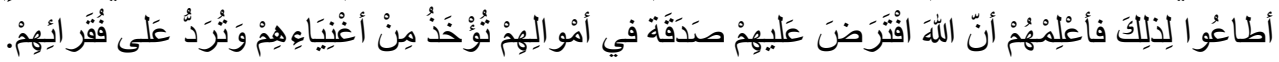

Artinya :

...dari Ibnu Abbas r.a. bahwa Nabi saw. mengutus Mu'āż r.a. ke Yaman seraya bersabda; Serulah mereka kepada persaksian bahwa tidak ada Tuhan yang berhak disembah kecuali Allah dan sesungguhnya aku adalah utusan Allah. Apabila mereka menaatinya, maka beritahukan bahwa Allah mewajibkan kepada mereka şalat lima waktu setiap hari dan malam. Apabila mereka manaatinya,maka beritahukan bahwa Allah mewajibkan kepada mereka sedekah (zakat) dalam harta mereka yang diambil dari orang-orang kaya di antara mereka lalu diberikan kepada orang-orang miskin mereka. (Al-Bukhary, tt)

Berdasarkan hadis tersebut, maka zakat merupakan solusi untuk mengatasi masalah kemiskinan. Zakat tidak harus dipandang sebatas kewajiban ibadah saja, tetapi zakat juga merupakan instrumen fiskal yang bisa mensejahterakan rakyat.

Zakat sejatinya merupakan manifestasi dari kegotongroyongan antara orang kaya dengan orang miskin. Sehingga pemberdayaan zakat pada hakikatnya merupakan perlindungan bagi masyarakat dari bencana kemiskinan, kelemahan, baik fisik maupun mental. Lembaga zakat merupakan sarana distribusi kekayaan di dalam ajaran Islam, juga sebagai bentuk kewajiban kolektif perekonomian umat Islam. (Agama, 2007)

Satu hal yang sangat menarik adalah Allah swt. membandingkan antara zakat dan riba. Zakat, meskipun secara nominal mengurangi harta, tetapi pada hakikatnya menambah harta di sisi Allah swt. Sedangkan riba, meskipun secara nominal menambah harta, namun pada hakikatnya justru mengurangi harta di sisi Allah swt., sebagaimana firman-Nya Q.S. al-Rūm/ 30: 39 .
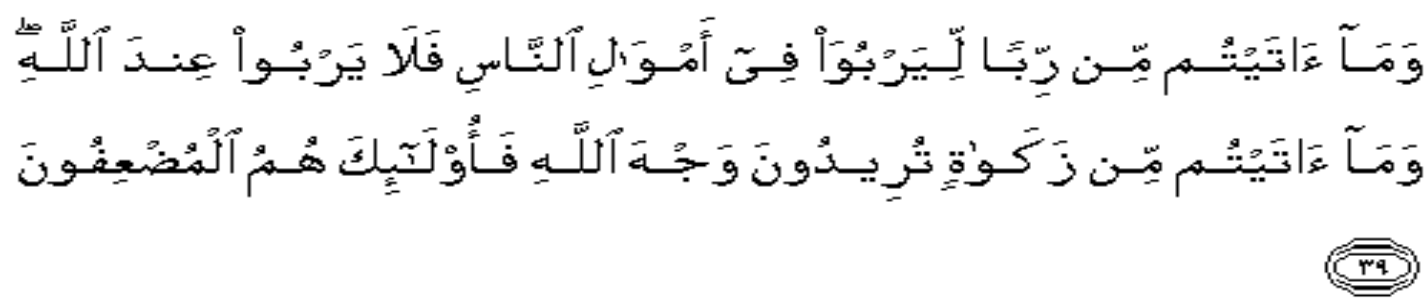

Terjemahnya:

Dan sesuatu riba (tambahan) yang kamu berikan agar dia bertambah pada harta manusia, Maka riba itu tidak menambah pada sisi Allah. dan apa yang kamu berikan berupa zakat 
yang kamu maksudkan untuk mencapai keridaan Allah, Maka (yang berbuat demikian) Itulah orang-orang yang melipat gandakan (pahalanya).

Kalau dicermati, boleh jadi di balik perbandingan tersebut, Islam menginginkan umatnya untuk memiliki paradigma bahwa zakat sesungguhnya bukan sekadar charity atau kedermawanan sosial. Ia merupakan bentuk investasi yang bersifat ukhrawi dan duniawi. Bertambahnya harta yang dikeluarkan zakatnya di sisi Allah swt. menunjukkan bahwa ia pada hakikatnya merupakan investasi yang bersifat ukhrawi. Sedangkan yang bersifat duniawi adalah zakat dapat mendorong pembukaan lapangan pekerjaan baru, sehingga akan meningkatkan pendapatan dan daya beli kaum du'afa. Peningkatan tersebut pada akhirnya akan mendorong tumbuhnya perekonomian masyarakat.

Dengan paradigma demikian, diharapkan akan muncul kesadaran dan orientasi masyarakat yang lebih mencintai untuk memberi dari pada menerima. Dengan semangat ini pula, masyarakat akan terpacu untuk meningkatkan produktivitasnya dan mengoptimalkan segala potensi yang dimilikinya, sebab bagaimana mungkin ia akan mampu memberi dan berinvestasi jika ia tidak produktif menghasilkan sesuatu. Tipe masyarakat yang produktif inilah yang sesungguhnya menjadi dasar pembangunan peradaban Islam di masa depan.

Isu-isu yang muncul di seputar masalah keberhasilan pengumpulan zakat, Direktorat Pemberdayaan Zakat menyimpulkan ada empat faktor permasalahan utama yang menyebabkan rendahnya realisasi potensi zakat, yaitu faktor kelembagaan, faktor masyarakat, faktor sistem yang dianut dalam pengelolaan zakat dan perlunya perluasan cakupan harta wajib zakat. Masih rendahnya kepercayaan masyarakat terhadap Lembaga Pengelola Zakat, sehingga hanya sebagian kecil saja yang menyalurkan zakatnya kepada lembaga pengelola tersebut. Kesadaran masyarakat untuk membayar zakat hartanya (termasuk zakat penghasilan/profesi, zakat perdagangan, zakat simpanan, dan lain sebagainya) masih minim, sebagian masyarakat hanya mengenal zakat fitrah saja. Dari segi sistem, manajemen pengelolaan zakat masih dikelola secara parsial, belum dilakukan secara terpadu, komprehensif dan sinergis.

Pada Milad ke-8 Badan Amil Zakat Nasional (BAZNAS), Susilo Bambang Yudoyono menyerukan kepada umat muslim Indonesia untuk gemar berzakat. Menurutnya, berzakat merupakan salah satu cara bagi muslim Indonesia untuk membangun kembali kejayaan peradaban Islam yang sangat mulia. (Yudoyono, 2009)

Pada pembukaan Festival Ekonomi Syariah (FES) Kedua tahun 2009 di Balai Sidang Jakarta, Jakarta, Rabu (4/2), Susilo Bambang Yudoyono menegaskan kembali pentingnya pemberdayaan zakat. Lebih lanjut dikatakan:

Pemberdayaan ZIS sangat penting dilakukan dalam pembangunan nasional. Alasannya, ZIS akan berdampak positif bagi program pengentasan kemiskinan dan pemberdayaan masyarakat. Oleh karena itu, harus segera dilakukan revitalisasi di sektor pengelolaan zakat, infak, dan sedekah sehingga dapat menjadi pendamping pelaku keuangan syariah yang potensial.

Mencermati seruan Presiden tersebut dan melihat kondisi pengelolaan zakat di tanah air dewasa ini, termasuk daerah Sulawesi Tenggara yang belum memberikan hasil yang 
optimal. Padahal pengelolaan zakat telah ditopang oleh sebuah perangkat hukum, yaitu Undang-Undang No. 38 Tahun 1999 tentang Pengelolaan Zakat. Oleh karena itu, gerakan pemberdayaan zakat, infaq dan sedekah merupakan suatu keniscayaan yang harus didukung oleh semua pihak untuk mendukung pembangunan ekonomi umat. Menurut Didin Hafidhuddin; "Zakat harus dilihat sebagai sebuah instrumen ekonomi umat."

Sulawesi Tenggara, khususnya Kota Kendari dengan mayoritas penduduknya beragama Islam adalah daerah yang memiliki potensi zakat sangat besar. Potensi ini merupakan sumber pendanaan yang dapat dijadikan kekuatan pemberdayaan ekonomi, pemerataan pendapatan dan bahkan akan dapat meningkatkan perekonomian umat.

Berdasarkan sensus penduduk Sulawesi Tenggara tahun 2008 yang diterbitkan oleh Badan Pusat Statistik (BPS) Provinsi Sulawesi Tenggara, bahwa jumlah penduduk Sulawesi Tenggara sebanyak 2.031.532 jiwa, jumlah tersebut tersebar pada dua belas Kabupaten dan Kota se Sulawesi Tenggara. (Statistik, 2008) Kendari yang merupakan Ibu kota Provinsi Sulawesi Tenggara jumlah penduduknya pada tahun 2008 tercatat sebanyak 251.477 jiwa, yang beragama Islam sebanyak 227.655 jiwa atau 90,53 \%, dan terdiri dari 56.118 rumah tangga. Dari jumlah tersebut yang menerima Bantuan Langsung Tunai (BLT) dari Pemerintah sebesar 21.749 rumah tangga.

Pada tatanan masyarakat Islam, dikenal ada dua golongan dalam masyarakat, yaitu golongan mampu (kaya) dan golongan tidak mampu (fakir, miskin). Golongan yang mampu dalam perspektif zakat disebut Muzakki, sedang golongan yang tidak mampu disebut Mustahik. Dengan mengacu pada data rumah tangga penerima BLT dan yang tidak menerima BLT, ada sebanyak 34.369 rumah tangga yang tidak menerima BLT. Jika kelompok ini diasumsikan sebagai kelompok muzakki dan mau mengeluarkan zakat hartanya, maka dalam satu tahun akan terkumpul dana zakat sebesar Rp. 23.693.988.600,- dengan asumsi perhitungan sebagai berikut, harga emas murni Rp. 300.000,-/gram x 91,92 gram emas murni (Agama, undang-undang republik indonesia nomor 38 tahun 1999 tentang pengelolaan zakat, pada lampiran 1: pedoman menghitung zakat sendiri, 2008) $=\mathrm{Rp} .27 .576 .000,-\mathrm{x} 2,5 \%=\mathrm{Rp}$. 689.400,- sehingga dari jumlah penduduk yang termasuk kelompok muzakki 34.369 rumah tangga mau mengeluarkan zakat hartanya, maka minimal akan terkumpul dana zakat setiap tahunnya sebanyak Rp. 689.400,- x 34.369 rumah tangga = Rp. 23.693.988.600,- atau setiap bulannya sebesar Rp. 1.974.499.050,- . belum lagi jika ditambah dengan zakat fitrah, infaq, sedekah, misalnya, tentu akan diperoleh angka yang lebih besar lagi, namun kenyataannya zakat yang terkumpul melalui Badan Amil Zakat (BAZ) Kota Kendari tahun 2008 sebesar Rp. 4.077.000,- (Agama U. D., 2008) Hal ini menunjukkan bahwa potensi zakat tersebut masih sekedar potensi, belum digali dan diberdayakan secara optimal.

Word. Penulis bertanggungjawab sepenuhnya terhadap naskah yang ditulis dan naskah merupakan tulisan yang belum pernah dipublikasikan.

\section{TINJAUAN TEORITIK}

Dalam penyusunan karya ilmiah dibutuhkan adanya berbagai dukungan teori dari berbagai sumber atau rujukan yang mempunyai relevansi yang kuat dengan rencana suatu 
penelitian. Beberapa sumber literasi yang menurut peneliti mempunyai relevansi yang kuat, seperti tesis, buku-buku dan berbagai rujukan yang terkait.

Penelitian yang dilakukan oleh mujahidin menunjukkan adanya peran zakat dalam meningkatkan perekeonomian masyarakat dengan skema yang digunakan ada zakat produktif. (Mujahidin, 2019) dalam penelitiannya yang lain bahwa untuk meningkatkan kesejahteraan masyarakat lewat zakat maka diperlukan efektifitas dalam mengumpulkan dan memaksimalkan potensi zakat di wilayah itu sehingga pengumpulan zakat yang maksimal dan efektiv akan memberikan kesejahteraan kepada masyarakat, melalui penyaluran zakat sebab jika zakat yang terkumpul jumlahnya sedikit maka yang akan dibagikan tidak akan mampu mengangkat taraf hidup masyarakat artinya paling hanya akan memberikan bantuan yang konsumtif. Belum bisa menyasar bantuan yang bersifat produktif padahal inilah yang bisa meningkatkan kesejahteraan masyarakat (mujahidin, 2019).

Seperti buku yang berjudul Manajemen Pengelolaan Zakat dan buku Juklak Pemberdayaan Zakat yang diterbitkan oleh Direktorat Pemberdayaan Zakat Ditjen Bimas Islam Departemen Agama, 2007, yang menguraikan tentang berbagai hal berkaitan dengan manajemen pengelolaan zakat, agar dapat tercipta pengelolaan zakat yang amanah, profesional dan transparan, seperti yang diamanatkan oleh Undang-undang No. 38 Tahun 1999 tentang Pengelolaan Zakat, sehingga potensi zakat yang ada di masyarakat dapat berhasil guna dan berdaya guna sebagaimana yang diharapkan.

Kemudian buku Kemitraan dalam Pengelolaan Zakat yang juga diterbitkan oleh Direktorat Pemberdayaan Zakat Ditjen Bimas Islam, 2007, yang menguraiakan tentang sejarah perkembangan zakat, kebutuhan menuju kemitraan, kerangka model kemitraan dan contoh kemitraan lembaga pengelola zakat, sehingga sisi sosial dari zakat tersebut betul-betul terasa membumi.

Selanjutnya buku Hukum Zakat (Fiqh Zakat) oleh Yusuf Qaraḍawi, 1996, yang menguraikan secara panjang lebar tentang zakat, bagaimana kedudukannnya dalam Islam, siapakah yang wajib berzakat, kekayaan apa saja yang wajib dizakati dan berapa besar zakatnya, sasaran zakat, bagaimana cara membayar zakat sampai kepada tujuan zakat dan dampaknya baik dalam kehidupan peribadi maupun masyarakat. Dikupas pula tentang korelasi antara zakat dan pajak, bagaimana titik persamaannya dan bagaimana pula perbedaannya. Juga disinggung tentang zakat dalam perekonomian modern, seperti investasi pabrik, saham, obligasi dan lain-lain.

Lebih lanjut dalam Buku Zakat dalam Perekonomian Modern oleh Didin Hafidhuddin, 2002, dikupas tentang sumber-sumber zakat yang tidak hanya terbatas pada sumber-sumer konvensional saja yang secara jelas dinyatakan dalam al-Qur'an dan Hadis yang wajib dikeluarkan zakatnya (al-amwāl al-zakawiyyah), namun diuraikan pula tentang sumbersumber zakat yang berkaitan dengan kegiatan perekonomian yang terus berkembang, antara lain meliputi surat-surat berharga, investasi, dan sektor perekonomian modern lainnya.

Dalam bentuk karya tulis ilmiah berupa disertasi dan tesis yang mempunyai kaitan dengan penelitian ini antara lain karya Ali Parman, sebuah Disertasi Doktor pada PPS UIN Alauddin Makassar tahun 2007 dengan judul Ketaatan Berzakat, Telaah Hukum Islam dan Implikasinya terhadap Manajemen Zakat di Kota Makassar. 
Karya Syamsul Bahtiar Fauzi, sebuah tesis pada PPS Universitas Haluoleo Kendari tahun 2008 dengan judul Faktor-Faktor yang Mempengaruhi Muzakki dalam Membayar Zakat Mãl di Kota Kendari. Tekanan utamanya menyangkut faktor-faktor yang mempengaruhi kesadaran muzakki dalam membayar zakat māl dan bagaimana pula tingkat kesadaran muzakki Kota Kendari dalam membayar zakat māl.

Karya Rahmading, sebuah tesis pada PPS UMI Makassar tahun 2005 dengan judul Implementasi Pengumpulan dan Pendistribusian Zakat Menurut Undang-Undang Nomor 38 Tahun 1999 Di Kota Kendari. Penekanan utamanya pada masalah implementasi UndangUndang Nomor 38 Tahun 1999 oleh Lembaga Pengelola Zakat di Kota Kendari dan faktorfaktor apa saja yang mempengaruhinya.

Karya A. Intang Dulung, sebuah tesis pada PPS UIN Alauddin Makassar tahun 2007 dengan judul Implementasi Undang-Undang Nomor 38 Tahun 1999 tentang Pengelolaan Zakat di Kabupaten Kolaka. Penekanan utamanya pada masalah implementasi UndangUndang Nomor 38 Tahun 1999 oleh Lembaga Pengelola Zakat di Kabupaten Kolaka dan faktor-faktor yang berpengaruh terhadap pelaksanaan Undang-undang tersebut.

Dari berbagai buku dan karya tulis ilmiah tersebut di atas tidak satupun yang membahas seperti apa yang dibahas oleh penulis, sekalipun ada unsur yang sama di dalam satu aspek, yaitu aspek pengumpulan dan pendayagunaan zakat sebagai salah satu obyek dari rencana penelitian ini. Semua rujukan yang disebutkan di atas menjadi bahagian dari sumber-sumber lainnya yang tidak dapat disebutkan satu persatu, mengingat keterbatasan waktu dan kesempatan, tetapi semuanya menjadi bahan masukan dan informasi yang sangat berharga dalam melaksanakan penelitian selanjutnya.

\section{METODE PENELITIAN}

Penelitian ini adalah penelitian lapangan ( field research) dan jenisnya adalah deskriptif kualitatif. yang dimaksud dengan penelitian deskriptif kualitatif dalam tesis ini adalah untuk mengungkap secara faktual dan sistematis mengenai peranan zakat bagi pengembangan ekonomi umat dan langkah strategis apa yang harus ditempuh dalam memberdayakan zakat agar lebih berhasil guna dan berdaya guna, mampu mendatangkan manfaat, efisien serta tepat guna. Dan bagaimana pula persepsi masyarakat tentang pengaruh pemberdayaan zakat terhadap pengembangan ekonomi umat di Kota Kendari. Dengan demikian fokus penelitian dalam tesis ini adalah Badan Amil Zakat Daerah (BAZDA) Kota Kendari, Muzakki dan Mustahik, kesemuanya berjumlah 50 orang yang tersebar di tiga wilayah Kecamatan. Jumlah 50 orang tersebut diperoleh dari $10 \%$ jumlah populasi yang ada di tiga wilayah kecamatan, masing-masing: (1) Wilayah Kecamatan Mandonga jumlah populasi keluarga miskin (kelompok mustahik) 162 keluarga, $10 \%$ dari jumlah tersebut adalah 16,2 dibulatkan menjadi 16 orang, (2) Wilayah Kecamatan Kadia jumlah populasi keluarga miskin 139 keluarga, $10 \%$ dari jumlah tersebut 13.9, dibulatkan menjadi 14 orang (3) Wilayah Kecamatan Baruga jumlah populasi keluarga miskin 203 keluarga, $10 \%$ dari jumlah tersebut 20,3 dibulatkan menjadi 20 orang. Sehingga jumlah sample dari ketiga kecamatan tersebut sebanyak 50 orang. 


\section{HASIL DAN PEMBAHASAN}

Upaya untuk membuktikan hipotesis yang diajukan dalam tesis ini, bahwa pemberdayaan zakat di Kota Kendari dapat mempengaruhi pengembangan ekonomi umat, maka harus dapat didukung dengan hasil research atau penelitian yang berupa fakta-fakta empiris dan data yang diperoleh dari lokasi penelitian, baik itu melalui pendekatan wawancara langsung dengan responden, perantaraan kusioner maupun hasil pengamatan langsung selama dilakukannya penelitian.

Data zakat yang diperoleh penulis dari Badan Amil Zakat Daerah (BAZDA) Kota Kendari bahwa pada tahun 2008 dana zakat yang terkumpul melalui Badan Amil Zakat (BAZ) Kota Kendari dari UPZ Kanwil Dep. Agama Prov. Sultra sebesar Rp. 4.077.000,- Hal ini menunjukkan bahwa potensi zakat tersebut masih sekedar potensi, belum digali dan diberdayakan secara optimal.

Data ini diperkuat dengan hasil wawancara dari salah seorang informan yaitu Kepala Kantor Departemen Agama Kota Kendari bapak Zainuddin, beliau menyatakan bahwa:

Potensi zakat di Kota Kendari sebenarnya banyak, dengan melihat komunitas masyarakat Kota Kendari yang mayoritas muslim, dan banyak bekerja di berbagai sektor, bukan hanya sektor perdagangan dan pertanian saja, melainkan sudah merambah pada sektor jasa dan sektor-sektor lain yang selama ini belum tersentuh sebagai bagian dari obyek harta wajib zakat, kesemuanya itu merupakan potensi zakat yang menjanjikan, jika potensi tersebut mampu digali dan dikelola secara profesional dan bertanggung jawab. Hanya saja sampai dengan diterbitkannya Perda Kota Kendari Nomor 1 Tahun 2008 hingga sekarang kepengurusan lembaga pengelola zakat Kota Kendari (BAZDA) belum terbentuk, sementara kepengurusan yang lama telah habis masa baktinya. Akibat dari kesemuanya itu, masalah zakat di Kota Kendari belum dapat ditangani secara serius dan belum mampu memberikan kontribusi yang nyata dalam usaha mengentaskan kimiskinan dan membangun ekonomi umat di Kota Kendari.

Hal senada juga dikemukakan informan lainnya yaitu pak Mambi penyelenggara zakat dan wakaf kandep kota Kendari, sebagai berikut

Bahwa masalah pemberdayaan zakat di Kota Kendari masih dalam batas program dari kepengurusan BAZDA yang telah habis masa baktinya, belum menyentuh pada segmen aplikasi, sehingga belum nampak hasil yang dirasakan oleh masyarakat, khususnya kaum du'afa. Kegiatan-kegiatan yang selama ini dilaksanakan juga masih dalam batas sosialisasi dan upaya meingkatkan pemahaman masyarakat akan arti pentingnya zakat dikelosla oleh sebuah lembaga pengelola yang profesional dan bertanggung jawab serta berorientasi pada nilai produktivitas zakat.

Pernyataan di atas dipertegas lagi oleh Syawal Sitanggang Kepala Seksi Penamas dan Pekapontren yang sebelumnya mejabat sebagai Kepala Seksi Penyelenggara Zakat dan Wakaf Kantor Departemen Agama Kota Kendari, serta anggota pengurus BAZDA periode kepengurusan yang telah habis masa baktinya, bersama empat orang Kepala KUA Kecamatan yang menyatakan bahwa: 
Permasalahan zakat di Kota Kendari masih harus dipacu, baik menyangkut masalah penghimpunan, pendistribusian maupun pendayagunaannya, agar dapat memberikan kontribusi yang nyata dalam meningkatkan perekonomian dan kesejahteraan umat. Demikian pula dalam upaya membangun kesadaran masyarakat akan kewajiban agamanya, khususnya dalam penunaian zakat, sehingga bukan hanya kewajiban zakat fitrah saja yang mereka tunaikan pada setiap 'Idul Fitri, namun kewajiban yang berkaitan dengan hak-hak orang lain (berupa zakat harta) yang melekat pada harta yang mereka dapatkan, juga harus ditingkatkan, sehingga mereka mau menunaikannya dengan penuh kesadaran.

Dengan data tersebut di atas dapatlah disimpulkan bahwa pemberdayaan zakat di Kota Kendari belum berjalan secara efektif dan belum memberikan hasil yang dapat dirasakan oleh masyarakat, khususnya kaum $d u$ 'afa. Walaupun disadari bahwa jika potensi zakat itu digali dan dikelola serta diberdayakan secara optimal akan dapat mempengaruhi pertumbuhan ekonomi umat dan dapat meningkatkan kesejahteraan umat, khususnya kaum $d u$ 'afa. Dalam hal perlunya pemberdayaan zakat ditangani secara khusus oleh lembaga pengelola zakat (BAZDA) dapat dilihat pada tabel berikut:

Tabel 09

Jawaban responden tentang perlunya pemberdayaan zakat ditangani secara khusus oleh lembaga pengelola zakat yang kredibel di Kota Kendari

\begin{tabular}{|l|l|c|c|}
\hline No. & \multicolumn{1}{|c|}{ Indikator } & Frekuensi & Persentase \\
\hline & & & 54,00 \\
1. & Sangat setuju & 27 & 32,00 \\
2. & Setuju & 16 & 10,00 \\
3. & Kurang setuju & 5 & 4,00 \\
4. & & 2 & \\
& Tidak setuju & & $\mathbf{1 0 0 , 0 0}$ \\
\hline
\end{tabular}

Sumber data : Diolah dari kuisioner Penelitian Tahun 2009

Dari tabel diatas diketahui bahwa responden yang menjawab sangat setuju sebanyak 27 orang ( 54\%), responden yang menjawab setuju sebanyak 16 orang (32\%), responden yang menjawab kurang setuju sebanyak 5 orang ( $10 \%$ ) dan responden yang menjawab tidak setuju sebanyak 2 orang ( $4 \%$ ). Dari data tersebut dapat diinterpretasikan bahwa pada dasarnya masyarakat menghendaki adanya zakat dan pemberdayaannya dikelola secara profesional dan bertanggung jawab oleh lembaga pengelola zakat, seperti BAZDA dan lembaga pengelola lain (LAZ).

Dalam kaitan optimalisasi fungsi dan peran BAZDA, berikut ini hasil wawancara dengan salah seorang informan bapak H. Amri Natsir dari Bagian Kesra Pemda Kota Kendari, yang menyatakan: 
Zakat memiliki peranan penting dalam pembangunan tatanan sosial dan ekonomi umat Islam, ia ikut andil dalam meningkatkan taraf perekonomian kaum fakir miskin, mencetak mereka menjadi suatu kekuatan yang produktif, dan merealisasikan garis jaminan sosial terhadap mereka yang kurang mampu, sehingga tidak ada kesenjangan yang mencolok antara si kaya dan si miskin. Namun tentunya paradigma ini akan membumi, jika potensi zakat betul-betul digali dan dikelola serta diberdayakan secara optimal. Pemda Kota Kendari dalam peranannya sebagai regulator, motivator dan fasilitator telah memberikan dukungan, baik berupa sarana dan bantuan biaya operasional kepada Lembaga Pengelola Zakat, seperti BAZDA agar dapat meningkatkan kinerjanya dalam pengelolaan zakat. Namun itu semua tentunya harus didukung oleh kepengurusan yang solid dan berdidikasi tinggi dalam usaha meningkatkan ekonomi masyarakat. Karena itu, yang harus dilaksanakan oleh BAZDA Kota Kendari adalah segera membenahi lembaga pengelola tersebut, termasuk membentuk kepengurusan baru yang definitif.

Data tersebut diperkuat oleh H. Tamrin, Kepala Bidang Penyelenggaraan Haji Zakat dan Wakaf Kanwil Dep. Agama Kota Kendari, beliau menyatakan bahwa:

Potensi zakat yang demikian besar di Kota Kendari akan mampu memberikan kontribusi yang signifikan bagi pembangunan ekonomi umat di Kota Kendari pada khususnya dan Prov. Sulawesi Tenggara pada umumnya, jika potensi tersebut mampu dioptimalkan dan diberdayakan secara maksimal serta dikelola oleh lembaga pengelola zakat yang profesional dan kredibel. Sepanjang belum ada lembaga pengelola zakat yang profesional dan kredibel, maka tingkat kepercayaan masyarakat terhadap lembaga pengelola rendah, akibatnya potensi zakat tidak dapat dioptimalkan, mereka lebih memilih personal yang lebih mereka percayai untuk menerima zakatnya. Dalam kondisi seperti ini biasanya, zakat akan lebih bersifat konsumtif, karena orientasinya untuk memenuhi kebutuhan sesaat, dan tentu hanya beberapa gelintir orang yang dapat merasakannya. Sehingga tujuan pemberdayaan zakat tidak akan tercapai.

Demikian pula yang dikemukakan H. M. Chadid, tokoh masyarakat Kendari dan Ketua Harian MUI Sulawesi Tenggara, beliau mengatakan bahwa:

Melihat perkembangan pemberdayaan zakat di Kota Kendari pada khususnya dan Sulawesi Tenggara pada umumnya, maka dalam rangka meningkatkan realisasi potensi zakat ada empat langkah yang harus ditempuh ; (1) penguatan lembaga, baik dari sisi lembaganya itu sendiri maupun kualitas sumber daya pengelolanya serta sikap amanah dari para pengelola. Sehingga kepercayaan masyarakat akan meningkat. (2) sosialisasi secara luas dan terpadu sehingga akan mampu mendongkrak kesadaran masyarakat untuk menunaikan kewajiban zakatnya, (3) pemetaan data muzakki dan mustahik, (4) dikelola melalui sistem manajemen zakat yang terpadu. Jika hal itu dapat dilaksanakan, maka potensi zakat tersebut akan dapat direalisasikan dan dioptimalkan serta pada gilirannya tingkat kesejahteraan umat dapat ditingkatkan pula. 
Hal serupa diungkapkan H. Djakrin Napu tokoh masyarakat Kota Kendari mengatakan bahwa:

Sudah saatnya zakat itu dikelola oleh suatu lembaga pengelola zakat yang amanah dan profesional, agar potensi zakat itu dapat dioptimalkan, sehingga hikmah dan dampak zakat dapat dirasakan manfaatnya secara luas oleh masyarakat, khususnya kaum $d u$ 'afa dan mustahik lainnya ke arah kehidupan yang lebih baik dan lebih sejahtera.

Pendapat senada disampaikan salah seorang informan H. Hamzah, tokoh masyarakat yang menyatakan bahwa:

Jika potensi zakat yang ada di Kota Kendari dioptimalkan penghimpunannya, kemudian diberdayakan secara maksimal untuk kesejahteraan mustahik, maka pemerintah Kota Kendari tidak perlu lagi menggulirkan program "Persaudaraan Madani", persaudaraan yang mewadahi antara keluarga mampu dengan keluarga tidak mampu, yang dilakukan atas kesadaran sosial yang tinggi, yang memungkinkan keluarga mampu dapat mengangkat derajat kehidupan saudaranya yang tidak mampu. Letak persoalannya adalah bagaimana mengembalikan image negatif masyarakat terhadap lembaga pengelola zakat yang selama ini kurang kondusif, sehingga hanya sebagaian kecil saja yang menyalurkan zakatnya kepada lembaga pengelola zakat. Jika faktor kelembagaan ini mampu dibenahi, ditambah dengan faktor kesadaran masyarakat untuk membayar zakat hartanya sudah meningkat, dan faktor manajemen pengelolaannya sudah baik, maka masalah potensi zakat akan dapat direalisasikan dan pada gilirannya program-program yang bersentuhan langsung dengan peningkatan kesejahteraan umat akan dapat direalisasikan. Namun jika faktor-faktor tersebut diabaikan, maka potensi zakat hanyalah sebatas potensi saja untuk selamanya tanpa pernah ada realisasinya.

Dari pendapat-pendapat tersebut dapatlah diinterpretasikan bahwa pemberdayaan zakat oleh lembaga pengelola zakat yang amanah, profesional, dan bertanggung jawab merupakan sebuah keniscayaan yang harus dilaksanakan untuk mendongkrak potensi zakat dan membangun peradaban zakat.

Berkaiatan dengan pengaruh pemberdayaan zakat bagi pengembangan ekonomi umat di Kota Kendari dapatlah dilihat dari hasil wawancara dengan seorang informan sebagai berikut:

Tidak diragukan lagi bahwa zakat merupakan salah satu bentuk konkret dari jaminan sosial yang disyariatkan oleh ajaran Islam. Melalui syariat zakat, kehidupan orang-orang fakir, miskin dan orang-orang yang menderita lainnya akan terperhatikan dengan baik. Jika zakat dikelola dengan baik, dimungkinkan akan mampu membangun pertumbuhan ekonomi sekaligus pemerataan pendapatan..Hanya saja sampai saat ini, pengaruh pemberdayaan zakat di Kota Kendari belum begitu signifikan dalam mengembangkan ekonomi umat. Jangankan tampak pengaruhnya, lembaganya pun masih perlu dibenahi.

Pembuktian lebih lanjut pengaruh pemberdayaan zakat terhadap perkembangan ekonomi umat di Kota Kendari, dapat dilihat dari hasil penelitian yang dilakukan penulis 
terhadap responden dengan menggunakan teknis kuisioner sebagaimana dapat dilihat pada tabel berikut :

Tabel 10

Jawaban responden tentang pengaruh pemberdayaan zakat terhadap pengembangan ekonomi umat di Kota Kendari (kondisi riil saat ini)

\begin{tabular}{|l|l|c|c|}
\hline No. & \multicolumn{1}{|c|}{ Indikator } & Frekuensi & Persentase \\
\hline & & & 4,00 \\
1. & Berpengaruh & 2 & 6,00 \\
2. & Kurang berpengaruh & 3 & 90,00 \\
3. & Tidak berpengaruh & 45 & \\
\hline & & & $\mathbf{1 0 0 , 0 0}$ \\
\hline
\end{tabular}

Sumber data: Diolah dari kuisioner Penelitian Tahun 2009

Berdasarkan tabel 10 tersebut, dapatlah diinterpretasikan bahwa pengaruh pemberdayaan zakat terhadap pengembangan ekonomi umat di Kota Kendari saat ini belum begitu signifikan pengaruhnya. Dari data tersebut yang menyatakan berpengaruh hanya 2 responden atau $4 \%$, yang menyatakan kurang berpengaruh 3 responden atau $6 \%$, sedang selebihnya menyatakan tidak berpengaruh. Jumlah yang menyatakan tidak berpengaruh dari responden yang diteliti sebanyak 45 responden atau $90 \%$. Hal ini disebabkan karena lembaga pengelola zakat seperti BAZDA Kota Kendari atau Lembaga Pengelola Zakat yang lain belum berfungsi sebagaimana yang diharapkan. BAZDA sebagai lembaga pengelola zakat yang diharapkan mampu memobilisasi potensi zakat di Kota Kendari dan mampu memberdayakannya untuk kepentingan dan kesejahteraan umat, ternyata belum dapat berbuat banyak. Saat ini BAZDA Kota Kendari, secara kelembagaan masih dalam batas pembenahan internal organisasi dan penataan manajemen pengelolaan. Program-program yang telah dilaksanakan juga masih pada tataran sosialisasi, belum menyentuh pada pola pemberdayaan zakat yang dapat meningkatkan kesejahteraan umat dan pertumbuhan ekonomi masyarakat. Tetapi jika lembaga pengelola zakat sudah mampu menjalankan peran dan fungsinya sebagaimana yang diamanatkan Undang-Undang RI Nomor 38 Tahun 1999 tentang Pengelolaan Zakat, maka angka kemiskinan akan dapat ditekan dan pertumbuhan ekonomi dikalangan masyarakat, khususnya fakir miskin akan meningkat. Hal ini dapat dicermati dari pendapat para responden yang tetap optimis bahkan yakin bahwa pemberdayaan zakat akan dapat mempengaruhi perkembangan ekonomi umat, jika potensi zakat yang ada di Kota Kendari mampu direalisasikan dan dikelola secara amanah, profesional, dan bertanggung jawab. Sebagai bukti sikap optimisme masyarakat dapat dilihat dari jawaban para responden sebagaimana tabel berikut ini:

Tabel 11

Persepsi responden tentang pengaruh pemberdayaan zakat terhadap pengembangan ekonomi umat di Kota Kendari, jika dikelola secara profesional dan bertanggung jawab oleh lembaga pengelola zakat yang akuntabel dan amanah

\begin{tabular}{|c|c|c|c|}
\hline No. & Indikator & Frekuensi & Persentase \\
\hline & & & \\
\hline
\end{tabular}




\begin{tabular}{|l|l|c|c|}
\hline 1. & Berpengaruh & 40 & 80,00 \\
2. & Kurang berpengaruh & 7 & 14,00 \\
3. & Tidak berpengaruh & 3 & 6,00 \\
\hline & Jumlah & $\mathbf{5 0}$ & $\mathbf{1 0 0 , 0 0}$ \\
\hline
\end{tabular}

Sumber data: Diolah dari kuisioner Penelitian Tahun 2009

Merujuk pada tabel 11 di atas, menunjukkan bahwa dari 50 responden yang telah dimintai tanggapannya berkenaan dengan pengaruh pemberdayaan zakat terhadap pengembangan ekonomi umat di Kota Kendari, diperoleh jawaban bahwa 40 responden menjawab berpengaruh, atau sama dengan $(80,00 \%)$, selebihnya 7 responden menjawab kurang berpengaruh, sama dengan $(14,00 \%)$ dan hanya 3 responden yang menjawab tidak berpengaruh atau sama dengan $(6,00 \%)$. Secara akumulasi persentase bahwa yang menjawab kurang berpengaruh ditambah dengan yang tidak berpengaruh, persentasenya lebih kecil dibanding dengan yang menjawab berpengaruh, sehingga dapat dikatakan bahwa persepsi responden tentang pemberdayaan zakat sangat berpengaruh terhadap pengembangan ekonomi umat di Kota Kendari, persentasenya lebih besar (80,00\%), sedang yang menjawab kurang berpengaruh dan tidak berpengaruh hanya $(14,00 \%+6,00 \%=20,00 \%)$. Ini menunjukkan bahwa potensi zakat di Kota Kendari, jika dioptimalkan pengelolaannya, mulai dari pengumpulan, pendistribusian dan pendayagunaannya serta dikelola secara profesional dan akuntabel, maka akan dapat mempengaruhi pertumbuhan ekonomi masyarakat dan pengentasan kemiskinan.di Kota Kendari.

Bilamana dihubungkan tabel demi tabel yang telah dikemukakan di atas, maka jelas terdapat sinkronisasi dan korelasi timbal balik yang saling mendukung dan menguatkan tentang pengaruh pemberdayaan zakat terhadap pengembangan ekonomi umat di Kota Kendari, jika potensi zakat yang ada di Kota Kendari mampu direalisasikan, dimobilisasi dan dikelola secara amanah, profesional dan bertanggung jawab oleh lembaga pengelola zakat yang kredibel dan amanah, niscaya kesejahteraan masyarakat akan mampu ditingkatkan, angka kemiskinan akan dapat ditekan. Tercatat bahwa yang tergolong keluarga miskin di Kota Kendari berdasarkan kriteria yang ditetapkan oleh Pemda Kota Kendari (Badan Pemberdayaan Masarakat / BPM) sebanyak 20.893 keluarga, dari jumlah tersebut yang tergolong sangat miskin sebanyak 1.368 keluarga, selebihnya sebanyak 19.525 keluarga tergolong keluarga miskin biasa, dalam artian mereka memiliki tempat tinggal, ada sedikit penghasilan, namun antara pendapatan dan kebutuhan hidup sehari-hari tidak berimbang. ${ }^{1}$

Seiring dengan itu, jika potensi zakat tersebut mampu direalisasikan dan diberdayakan, pada gilirannya perkembangan ekonomi juga akan membaik, daya beli masyarakat akan meningkat, khususnya di kalangan masyarakat ekonomi lemah (kaum $d u$ 'afa). Dengan demikian, dapat disimpulkan bahwa semakin tinggi realisasi potensi zakat yang mampu digali dan diberdayakan akan semakin berpengaruh terhadap perkembangan ekonomi umat di Kota Kendari. 


\section{KESIMPULAN}

Berdasarkan berbagai pemaparan dan analisis hasil penelitian pada bab-bab sebelumnya dapat ditarik kesimpulan pokok, yang merupakan jawaban singkat dari permasalahan tesis ini sebagai berikut:

Peranan zakat terhadap pengembangan ekonomi umat di Kota Kendari belum dapat dirasakan manfaatnya secara signifikan oleh kaum du'afa, terlebih dalam mempengaruhi tingkat pendapatan ekonomi mereka. Zakat yang begitu menjanjikan dalam menjembatani distribusi pendapatan, meningkatkan kesejahteraan kaum $d u$ 'afa dan mengentaskan kemiskinan, belum dapat direalisasikan oleh BAZDA Kota Kendari sebagaimana yang diharapkan. Hal ini disebabkan karena belum optimalnya kinerja BAZDA dan belum mampu menggali potensipotensi zakat yang ada di Kota Kendari yang dapat diberdayakan untuk mengatasi problematika umat tersebut.

\section{DAFTAR PUSTAKA}

Agama, D. (2007). Petunjuk Pelaksanaan Pemberdayaan Zakat. Jakarta: Direktorat Pemberdayaan Zakat.

Agama, D. (2008). undang-undang republik indonesia nomor 38 tahun 1999 tentang pengelolaan zakat, pada lampiran 1: pedoman menghitung zakat sendiri. Jakarta: Direktorat pemberdayaan zakat.

Agama, U. D. (2008). zakat profesi karyawan Kanwil Depag Provinsi Sulawesi Tenggara. Kendari.

Al-Bukhary, M. b. (tt). Shahih Bukhary. Kairo: dar al-fikr.

Beik, I. S. (2008). pesantren virtual. Retrieved from pesantren virtual: http:/www.pesantrenvirtual.com/indeks

mujahidin. (2019). Efektifitas Pengumpulan Zakat Profesi (Studi pada BAZNAS di Kabupaten Maros). Palita: Journal of Social-Religion Research. DOI: https://doi.org/10.24256/pal.v3i2.452

Mujahidin. (2019). Tinjauan terhadap Pendistribusian Zakat Profesi dalam Peningkatan Kesejahteraan Masyarakat (Studi pada BAZNAS Kab. Maros). Journal al-tijary. DOI: https://doi.org/10.21093/at.v4i2.1367

Statistik, B. p. (2008). Sulawesi tenggara dalam angka. Kendar: Primatama.

Yudoyono, S. B. (2009). republika. Retrieved from republika: http:/www.republika.co.id/koran/29521 